\title{
Unit of Heat Flux Density
}

National Cancer Institute

\section{Source}

National Cancer Institute. Unit of Heat Flux Density. NCI Thesaurus. Code C69156.

A unit for measurement of a heat flow rate across a unit area. 